\title{
The Impact of the Sino-Indian Border Conflict on the Kashmir Issue
}

\author{
Pei Peng \\ School of Marxism, \\ Jianghan University \\ Wuhan, China
}

\begin{abstract}
The Sino-Indian border conflict had an important impact on the India-Pakistan Kashmir issue. The United States tried to push the India-Pakistan peace talks to resolve the Kashmir issue. It promoted the development of a friendly relationship between China and Pakistan. The rapid development of China-Pakistan relations made Pakistan's position more determined. India moved closer to the Soviet Union and became tougher on the Kashmir issue. The uncompromising attitude of India and Pakistan kept the Kashmir issue unresolved.
\end{abstract}

Keywords-Sino-Indian border conflict; Kashmir issue; ChinaIndia relations; China-Pakistan relations

\section{INTRODUCTION}

The Sino-Indian border conflict of 1959-1962 had a profound impact on the pattern of South Asia and also affected the settlement of the India-Kashmir issue. The United States tried to use the opportunity to promote India-Pakistan peace talks to resolve the Kashmir issue. The Sino-Indian border conflict promoted the development of friendly relations between China and Pakistan. The rapid development of ChinaPakistan relationship made Pakistan's position more determined. India moved closer to the Soviet Union, and India, which had strong support from the Soviet Union, became tougher on the Kashmir issue. The uncompromising attitude of India and Pakistan has kept the Kashmir issue unresolved.

\section{The United StATES AduUsted Its SOUTH Asian} POLICY AND TRIED TO USE THE OPPORTUNITY TO PROMOTE INDIA-PAKISTAN PEACE TALKS TO RESOLVE THE KASHMIR ISSUE

During the Cold War, containing the expansion of Communism in Asia was the basic starting point of the US South Asian policy. At the beginning of the Cold War, the main goal of the US South Asian policy was to encourage India and Pakistan to join the "free world" that would contain the threat of communism. However, India pursued a policy of nonalignment not joining any camps, and there were many differences between the United States and India on a number of international issues. At the same time, Pakistan was actively seeking cooperation with external forces to resolve its security dilemma. Therefore, the United States finally chose to form an alliance with Pakistan.[1] But the United States did not give up India, and used India as an "Asian democratic window" to provide economic assistance to compete with China and try to prevent India from falling to the Socialist Camp.
Beginning in the late 1950s, with the Sino-Indian border disputes revealed, the United States gradually adjusted its South Asian policy and further increased its economic assistance to India while assisting Pakistan. The United States believed that the opposition between India and Pakistan on the Kashmir issue wasted a lot of assistance from Western countries. In addition to the important strategic position of the Kashmir region, the United States proposed the Kashmir independence plan in 1952. After the failure of the plan, the United States was still looking for opportunities to facilitate India-Pakistan settlement on Kashmir issue.

The continued deterioration of Sino-Indian relations after the Tibet rebellion in 1959 made the United States believe that new opportunities were coming. The United States tried to promote India-Pakistan peace talks to resolve the Kashmir issue, and establish an "Indo-Pakistani joint defense system" against China, thereby pulling India to join Western Camp. With the support of the United States, Pakistan repeatedly proposed to India to build the "indo-Pakistan joint defense" proposal from 1959 to 1960, but it was rejected by India. India believed that the so-called "indo-Pakistan joint defense" was merely asking India to compromise on the Kashmir issue.[2] Despite the failure of the joint defense plan, the relationship between India and Pakistan had been improved in 1960. Under the mediation of the United States, India and Pakistan reached an agreement on the allocation of water resources in the Indus, which made the United States Encouraged.[3]

With the further escalation of the Sino-Indian border conflict, the United States increased the pace of South Asian policy adjustment in 1961. The United States greatly increased its economic assistance to India in exchange for India becoming a strategic partner for the United States to contain China. At the same time, the United States properly distanced itself from Pakistan. India became the focus of US South Asia policy and received more attention than Pakistan. In June 1961, the US-backed World Bank Aid India Club announced that it would provide India with approximately $\$ 2.2$ billion in aid over the next two years. US President's Special Envoy Evril Harriman, Vice President Lyndon Johnson and Deputy Secretary of State Bowers visited India in 1961. The relationship between India and the United States continued to heat up.

The actions of the United States caused strong dissatisfaction in Pakistan. On the one hand, Pakistan tried to improve its relations with China. In March 1961, it officially 
proposed to China to begin border negotiations. On the other hand, it exerted pressure on the United States to expect the United States to use aid to force India to negotiate with Pakistan to finally resolve the Kashmir issue. Although the Kennedy administration paid more attention to India, Pakistan was still an indispensable part of the US South Asian policy. Therefore, the United States understood Pakistan's requirements to a certain extent, and hoped that the Sino-Indian border conflict would lead to India-Pakistan reconciliation to fight against China.

On October 20, 1962, after a large-scale border conflict broke out between China and India, the United States immediately provided India with political and military support and assistance. On the one hand, it condemned China's "aggression". On the other hand, it stepped up its efforts to formulate emergency plans for aid to India. After India's formal request for military assistance, the first emergency military assistance from the United States was delivered to India on November 3. In view of Pakistan's strong protests and the United States' established South Asian policy objectives, the United States proposed after the delivery of the first batch of military aid: India's prerequisite for long-term US military assistance was India-Pakistan peace talks and final reconciliation, and the primary issue of India-Pakistan reconciliation was the Kashmir issue. In order to achieve a compromise between India and Pakistan, US President's Special Envoy Evril Harriman and Commonwealth Affairs Minister Duncan Sands arrived in India and Pakistan, putting pressure on the two countries. Under pressure from the United States, India agreed to negotiate with Pakistan.

From December 1962 to May 1963, India and Pakistan conducted six rounds of negotiations. However, due to the profound contradictions between India and Pakistan, and the huge differences on the Kashmir issue, the negotiations ended without results. The two sides issued a communiqué on May 17 1963, announcing the failure of the talks between the two countries on the Kashmir issue.[4]

\section{CHINA-INDIA BORDER CONFLICT AND CHINA'S KASHMIR POLICY}

Before the Sino-Indian relationship deteriorated completely in 1962, China had always held a neutral position on the Kashmir issue. Although Pakistan and India have repeatedly asked China to express its position on the Kashmir issue, China always adopted a mode of persuasion and hoped that the two countries will resolve their differences through consultation. Even in the best stage of Sino-Indian relations, China adhered to neutrality. During the visits to India in 1954 and 1956, Premier Zhou Enlai twice declined the Indian's invitation to visit Kashmir.[5] Since India's absolute advantage in power in South Asia relative to Pakistan at that time, China's neutrality was actually more beneficial to India. [6]

After the Sino-Indian relationship deteriorated in 1959 due to the Tibet issue and the border issue, China began to gradually adjust its South Asian policy. At that time, the Soviet Union publicly supported India on the Tibet issue and the border issue despite the alliance with China. In order to contain and encircle China, the United States increased its assistance to
India. Faced with this situation, China need to reassess its strategic interests in South Asia. At the same time, Pakistan was actively seeking to improve its relations with China because of its dissatisfaction with the large-scale assistance of the United States to India and its own security interests. Since February 1960, Pakistani political figures repeatedly issued signals in different forms of hope to negotiate borders with China and improve relations between the two countries. Before the end of 1961, China had not responded positively, mainly because the border negotiations between China and Pakistan involved a complicated Kashmir issue, and China was very dissatisfied with Pakistan's bet on both sides.[7] After the Tibet rebellion in 1959, Pakistan used the contradictions between China and India to repeatedly propose India's "common defense" proposal. India's refusal to make concessions on the Kashmir issue, and the continued warming of US-Indian relations had prompted Pakistan to change its policy toward China. Since 1961, Pakistan stopped publishing articles in the press against China and refused to participate in the conference on the containment of China held in Manila in early 1961 in Manila. In December 1961, Pakistan abstained from voting on the US proposal to obstruct China's legal seat in the United Nations and voted in favor of the Soviet proposal to restore China's legitimate seat in the United Nations.[8]

The continued deterioration of Sino-Indian relations after the Sino-Indian border conflict and the transformation of Pakistan's policies transformed China's policy toward Pakistan. China decided to hold border negotiations and develop relations with Pakistan. In February 1962, China informed the Palestinians that they were willing to negotiate on the border issue. In May 1962, China and Pakistan issued a communique to announce that border negotiations will be held. On October 12, 1962, the China-Pakistan border negotiations officially began; On March 2nd, China and Pakistan signed the "Agreement on China's Xinjiang and the borders of various regions that Pakistan actually controls its defense."Since then, China-Pakistan friendly relations developed rapidly. The two countries supported each other in politics, and the cooperation in the economic and cultural fields became increasingly frequent.

The rapid development of China-Pakistan friendly relations caused China's diplomatic balance between India and Pakistan to begin to tilt toward Pakistan.[9] China's policy on the Kashmir issue underwent subtle changes. China began to criticize India's Kashmir policy and stressed that the Kashmir issue should determine its ultimate affiliation on the basis of full respect for the people's right to self-determination in Kashmir. When Premier Zhou Enlai visited Pakistan in February 1964, China explicitly accepted Pakistan's reference to Kashmir in the joint communique issued by China and Pakistan. During the second India-Pakistan War in 1965, China not only clearly stood on the Pakistan side but also clearly expressed its support for Pakistan's recovery of Kashmir. Moreover, China issued three severely worded warnings to India, demanding that India immediately stop armed provocation against China, and India strongly condemned India's support for Pakistan's support. To a certain extent, China's support strengthened Pakistan's determination to compete with India. 


\section{SINO-INDIAN BORDER CONFLICT AND INDIA'S KASHMIR POLICY}

Before 1959, although India had great differences with Pakistan on the Kashmir issue, it basically agreed to hold a referendum when conditions were met. In 1954, Pakistan ignored the Indian warning and the alliance with the United States caused tensions between India and Pakistan. After that, India's position on the Kashmir issue began to change. It was not only unwilling to fulfill the "referendum" commitment but also refused mediation from Britain, the United States, the United Nations and any other parties.

The continuous escalation of the Sino-Indian border conflict after the Tibet rebellion in March 1959 made the United States think that "China's threat to South Asia" provided an opportunity for India and Pakistan to abandon their former suspicions and finally resolve the Kashmir issue. India was dissatisfied with the US's using of Sino-Indian relations to deteriorate and imposing pressure on India on the condition of military assistance, forcing India to compromise Pakistan on the Kashmir issue. However, in the United States' coercion and the emergency situation that may face a border war with China, India reluctantly agreed to negotiate with Pakistan. India and Pakistan issued a joint communique on November 29, 1962, announcing their readiness to resume negotiations on the Kashmir issue. However, on the second day of the publication of the communique, Nehru repeatedly assured parliamentarians in the parliament that they would not consider any opinions that would undermine the current situation in Kashmir. That was to say, what India requires was to solve the problem on the basis of the current situation in Kashmir. The biggest concession made by India in negotiations with Pakistan was only the adjustment of the ceasefire line, which was far from meeting Pakistan's minimum requirements for returning at least the Kashmir valley.[10] At the same time, Nehru repeatedly complained that the United States had used India's difficult situation with China to force India to make concessions on the Kashmir issue. On various occasions, Nehru said that India could not compromise with Pakistan after being humiliated by China in the Sino-Indian border war in 1962. Therefore, despite the six rounds of talks between India and Pakistan under the pressure of the United States, there was no possibility of any progress in the India-Pakistan negotiations.

Dissatisfaction with the United States' persecution of India's compromises and the urgent need for military assistance brought India closer to the Soviet Union. During the Sino-Indian border conflict, India's relations with the Soviet Union developed rapidly. The Soviet Union not only supported India politically and economically but also provided India with advanced military weapons rejected by the United States. On the Kashmir issue, the Soviet Union publicly supported India's position.

Before the Sino-Indian border conflict, although China was neutral on the Kashmir issue, the Indian government subjectively believed that China had accepted India's basic position on the Kashmir issue. When China and Pakistan began negotiations on the border between China and Pakistancontrolled Kashmir, India reacted strongly and believed that China-Pakistan border negotiations weakened India's position on the Kashmir issue. Therefore, India tried its best to intervene and obstruct the Sino-Pakistani border negotiations. However, India's intervention and obstruction strengthened the position of China and Pakistan in reaching a border agreement, thus promoting the process of China-Pakistan negotiations.[11] After the signing of the China-Pakistan border agreement in March 1963, India insisted that the border agreement reached between China and Pakistan was "illegal" and ineffective. At the end of 1964, India unilaterally announced the incorporation of Indian-controlled Kashmir as a state into India, which further intensified the contradictions between India and Pakistan on the Kashmir issue and eventually led to the second India-Pakistan war in 1965.

\section{SUMMARY}

The Sino-Indian border conflict of 1959-1962 had a profound impact on the pattern of South Asia and also affected the settlement of the India-Kashmir issue. The United States tried to use the opportunity to promote India-Pakistan peace talks to resolve the Kashmir issue. The Sino-Indian border conflict promoted the development of friendly relations between China and Pakistan. The rapid development of ChinaPakistan relationship made Pakistan's position more determined. India moved closer to the Soviet Union, and India, which had strong support from the Soviet Union, became tougher on the Kashmir issue. The uncompromising attitude of India and Pakistan has kept the Kashmir issue unresolved.

\section{REFERENCES}

[1] Wu Zhaoli, Evolution of US South Asia Policy: 1947-2000. South Asian Studies, 2007 (1).

[2] Zhang Zhongxiang, Nehru Diplomatic Studies. Beijing: China Social Sciences Press, 2002,p.108.

[3] Wang Chen, US Foreign Policy and the Balance of South Asia (19471963). Hong Kong: Hong Kong Social Science Press Ltd., 2005, pp.175176.

[4] John K.Calbraith, Ambassador's Journal: A Personal Account of the Kennedy Years. Houghton Miff-lin Company, 1969, p.509.

[5] Cheng Ruisheng, Hot spot in South Asia: Kashmir. International Culture Publishing Company, 2007, p.106.

[6] Zhang Li, China's South Asian Diplomacy and Kashmir Issues.South Asian Studies Quarterly, 2006 (1).

[7] Cheng Xiaohe, The Evolution of China-Pakistan Relations: 19621965.South Asian Studies, 2009 (4).

[8] Wang Taiping, Fifty Years of New China's Diplomacy. World Knowledge Press, 1999, p.238.

[9] Chen Hefeng, Relationship between China and South Asian Countries in the 1990s. Sichuan People's Publishing House, 1995, pp110.

[10] Alastair Lamb, Kashmir:A Disputed Legacy, 1846-1990. Karachi, 1992, p. 239.

[11] Han Xiaoqing, Unconscious "Promoter": Indian Factor in the SinoPakistani Border Negotiations. South Asian Studies, 2010 (3). 